\title{
Pengaruh Model Pembelajaran Kooperatif Tipe Numbered Head Together (NHT) Terhadap Hasil Belajar Matematika Siswa Kelas VII Berdasarkan Level Kemampuan Matematis
}

\author{
${ }^{1}$ Hayatun Nufus \\ ${ }^{2}$ Rezi Ariawan \\ ${ }^{3}$ Erdawati Nurdin \\ ${ }^{4}$ Hasanuddin \\ 1,3,4 Pendidikan Matematika Universitas Islam Negeri Sultan Syarif Kasim Riau \\ ${ }^{2}$ Pendidikan Matematika Universitas Islam Riau \\ E-mail:1hayatun.nufus@uins-suska.ac.id
}

\begin{abstract}
This study examines the problem of improving mathematics learning outcomes among students with cooperative learning model NHT type and conventional learning approaches is reviewed as a whole and for each level of mathematical ability (high, medium, and low). This research is a quasi-experimental research design Nonequivalent Control Group Design uses Simple Random Sampling technique. The population in this study were students of class VII in a private junior high school in the city of Pekanbaru in Riau in the academic year 2014/2015. While the sample is graders VII2 as control class and class VII2 as an experimental class. The instrument used in this study is the mathematics achievement test. Quantitative analysis was performed using two mean difference test. The results showed that: (1) there is significant implementation of cooperative learning model NHT on the results of students' mathematics learning is reviewed as a whole and the level of ability was; (2) there is no effect of the application of cooperative learning model NHT towards mathematics learning outcomes of students based on high and low-level capabilities.
\end{abstract}

Keywords: Cooperative Learning, Number Head Together, Mathematics Evaluation Result

\begin{abstract}
Abstrak
Penelitian ini mengkaji masalah peningkatan hasil belajar matematika antara siswa dengan model pembelajaran kooperatif tipe NHT dan pendekatan pembelajaran konvensional ditinjau secara keseluruhan dan untuk tiap level kemampuan matematis (tinggi, sedang, dan rendah). Penelitian ini merupakan penelitian kuasi eksperimen dengan desain penelitian Nonequivalent Control Group Design yang menggunakan teknik Simple Random Sampling. Populasi dalam penelitian ini adalah siswa kelas VII di salah satu SMP swasta di Kota Pekanbaru Riau Tahun Pelajaran 2014/2015. Sedangkan sampel dalam penelitian ini adalah siswa kelas $\mathrm{VII}_{2}$ sebagai kelas kontrol dan kelas $\mathrm{VII}_{2}$ sebagai kelas eksperimen. Instrumen yang digunakan dalam penelitian ini adalah tes hasil belajar matematika. Analisis kuantitatif dilakukan dengan menggunakan uji perbedaan dua rerata. Hasil penelitian menunjukkan bahwa: (1) terdapat pengaruh penerapan model pembelajaran kooperatif tipe NHT terhadap hasil belajar matematika siswa ditinjau secara keseluruhan dan level kemampuan sedang; (2) tidak terdapat pengaruh penerapan model pembelajaran kooperatif tipe NHT terhadap hasil belajar matematika siswa berdasarkan level kemampuan tinggi dan rendah.
\end{abstract}

Kata Kunci: Model Pembelajaran Kooperatif, Number Head Together (NHT), Hasil Belajar Matematika. 


\section{Pendahuluan}

Matematika adalah dikatakan sebagai ratu ilmu karena matematika banyak digunakan dibidang ilmu dan kajian lainnya dan matematika tidak dapat dipisahkan penggunaan dan penerapannya dari kehidupan manusia sehari-hari. Menurut Depdikbud1 "matematika sebagai salah satu mata pelajaran yang diberikan kepada siswa mempunyai peranan penting untuk menguasai ilmu pengetahuan dan teknologi”. Hal ini sejalan dengan pendapat Cokroft yang menyatakan bahwa matematika perlu diajarkan kepada siswa karena: ${ }^{2}$

1) Selalu digunakan dalam segala segi kehidupan

2) Semua bidang studi memerlukan keterampilan matematika yang sesuai

3) Merupakan sarana komunikasi yang kuat, singkat, dan jelas

4) Dapat digunakan untuk menyajikan informasi dalam berbagai cara

5) Meningkatkan kemampuan berpikir logis, ketelitian, dan kesadaran keruangan

6) Memberikan kepuasan terhadap usaha memecahkan masalah yang menantang.

Berdasarkan uraian di atas, maka penguasaan matematika menjadi hal yang mutlak harus dimiliki oleh generasi pada saat ini. Penggunaan dan pemanfaatan serta pengembangan teknologi modern pada saat ini menggunakan disiplin ilmu matematika, sehingga sudah menjadi keharusan penguasaan matematika itu sendiri.

Diajarkannya matematika pada setiap jenjang pendidikan mengacu pada dua tujuan, yaitu tujuan bersifat formal dan tujuan bersifat material. Tujuan ini sesuai dengan pendapat Soedjadi yang menyatakan bahwa "tujuan formal berkaitan dengan penataan nalar dan pembentukan sikap siswa, sedangkan tujuan material berkaitan dengan penggunaan atau penerapan matematika"3.

1 Suhermi and Sehatta Saragih, Strategi Pembelajaran Matematika (Pekanbaru: Cendekia Insani, 2006), 1.

2 Mulyono Abdurrahman, Pendidikan Bagi Anak Berkesulitan Belajar (Jakarta: Rineka Cipta, 2003), 253.

3 Soedjadi, Kiat Pendidikan Matematika Di Indonesia (Jakarta: Direktorat Jenderal Pendidikan Tinggi Departemen Pendidikan Nasional, 2000), 66. 
Menurut Brownell, matematika dapat dipandang sebagai suatu sistem yang terdiri atas ide, prinsip, dan proses sehingga keterkaitan antar aspekaspek tersebut harus dibangun dengan penekanan bukan pada memori atau hapalan melainkan pada aspek penalaran atau intelegensi anak ${ }^{4}$. Selanjutnya ditambahkan bahwa matematika itu haruslah make sense. Jika matematika disajikan kepada anak dengan cara yang demikian, maka konsep yang dipelajari menjadi punya arti; dipahami sebagai suatu disiplin yang terurut, terstruktur, dan memiliki keterkaitan satu dengan lainnya; serta diperoleh melalui proses pemecahan masalah yang bervariasi

Pembelajaran matematika bertujuan agar siswa memiliki kemampuan sebagai berikut :

1) Memahami konsep matematika, menjelaskan keterkaitan antar konsep atau algoritma secara luwes, akurat, efisien, dan tepat, dalam pemecahan masalah.

2) Menggunakan penalaran pada pola dan sifat, melakukan manipulasi matematika dalam membuat generalisasi, menyusun bukti, atau menjelaskan gagasan dan penghayatan matematika

3) Memecahkan masalah yang meliputi kemampuan memahami masalah, merancang model matematika, menyelesaikan model dan menafsirkan solusi yang diperoleh

4) Mengkomunikasikan gagasan dengan simbol, tabel, diagram, atau media lain untuk memperjelas keadaan atau masalah

5) Memiliki sikap menghargai kegunaan matematika dalam kehidupan, yaitu memiliki rasa ingin tahu, perhatian dan minat dalam mempelajari matematika, serta sikap ulet dan percaya diri dalam pemecahan masalah

Berdasarkan uraian di atas, jelas bahwa matematika merupan suatu bidang ilmu yang sangat penting. Oleh karena itu, sangatlah diharapkan siswa dapat menguasai konsep matematika dengan baik. Hal ini dapat dilihat dari hasil belajar yang diperoleh masing-masing siswa. Hasil belajar yang diharapkan adalah hasil belajar yang memuaskan sesuai dengan batasan kriteria yang berlaku. Namun, tidak begitu halnya dengan kondisi pada kenyataanya.

\footnotetext{
${ }^{4}$ Robert E Reys et al., Helping Children Learn Mathematics (Boston: Allyn and Bacon, n.d.).
}

Al-Khwarizmi - 31 
Temuan rendahnya kemampuan siswa Indonesia diperlihatkan dari hasil penelitian internasional seperti pada Programme for International Student Assesment (PISA) dan Trends in International Mathematics and Science Study (TIMSS). PISA bertujuan untuk menilai sejauh mana siswa yang duduk di akhir tahun pendidikan dasar (siswa berusia 15 tahun) telah menguasai pengetahuan dan keterampilan yang penting untuk dapat berpartisipasi sebagai warga negara atau anggota masyarakat yang membangun dan bertanggung jawab, yang meliputi kemampuan literasi matematika, literasi membaca, dan literasi sains. TIMSS bertujuan untuk menguji kemampuan matematis siswa kelas empat Sekolah Dasar dan kelas delapan Sekolah Menengah Pertama yang meliputi kemampuan pengetahuan, penerapan, dan penalaran.

Wardhani dan Rumiati menyatakan bahwa Indonesia mengikuti TIMSS pada tahun 1999, 2003, 2007, 2011, dan 2015 dan PISA tahun 2000, 2003, 2006, 2009, 2012, dan 2015 dengan hasil tidak menunjukkan banyak perubahan pada setiap keikutsertaan. Pada PISA tahun 2009 Indonesia hanya menduduki rangking 61 dari 65 peserta dengan rata-rata skor 371, sementara rata-rata skor internasional adalah 496. Prestasi pada TIMSS 2007 lebih memprihatinkan lagi, karena rata-rata skor siswa kelas 8 kita menurun menjadi 405, dibanding tahun 2003 yaitu 411. Rangking Indonesia pada TIMSS tahun 2007 menjadi rangking 36 dari 49 negara. Berikut ini adalah contoh soal terkait rendahnya kemampuan penalaran matematis siswa Indonesia di ajang TIMSS dan PISA yaitu pada salah satu soal dalam TIMSS tahun 20075

Menurut Yoppy Wahyu Purnomo salah satu penyebab rendahnya hasil belajar siswa adalah pandangan yang keliru terhadap peran guru. Pada umumnya guru mendominasi jalannya proses pembelajaran matematika di sekolah, selain itu murid hanya bersifat pasif dalam proses pembelajaran. ${ }^{6}$ Mengingat pentingnya pembelajaran matematika maka perlu adanya peningkatan hasil belajar matematika siswa.

${ }^{5}$ Wardhani S and Rumiati, Instrumen Penilaian Hasil Belajar Matematika SMP: Belajar Dari PISA Dan TIMSS (Yogyakarta: Kementrian Pendidikan Nasional : Pusat Pengembangan dan Pemberdayaan Pendidik dan Tenaga Kependidikan Matematika, 2011), 1.

${ }^{6}$ Yoppy Wahyu Purnomo, "Efektivitas Model Penemuan Terbimbing Dan Cooperative Learning Ditinjau Dari Kreativitas Siswa Pada Pembelajaran Matematika," 2011, 145, http://publikasiilmiah.ums.ac.id/bitstream/handle/123456789/609/MAK-YOPPY-(145154).pdf?sequence $=1$. 
Hasil belajar dapat diartikan sebagai kemampuan-kemampuan yang dimiliki siswa setelah ia mengalami pengalaman belajarnya ${ }^{7}$. Hal ini sejalan dengan pendapat yang menyatakan bahwa: hasil belajar siswa dapat diketahui dengan melakukan evaluasi, yaitu mengukur dan menilai dalam hal ini adalah menilai hasil kinerja siswa. Dengan mengukur hasil belajar, maka guru dapat mengetahui tingkat penguasaan materi pelajaran yang diajarkan. Hasil belajar dapat menjadi acuan bagi guru untuk mengetahui apakah metode yang digunakan sudah tepat atau belum ${ }^{8}$.

Melalui hasil wawancara yang dilakukan peneliti dengan guru bidang studi matematika kelas VII SMP YLPI Plus Marpoyan Pekanbaru semester ganjil pada tanggal 14 November 2014, diketahui bahwa 21 siswa atau 58,33\% yang tidak mencapai KKM dari 36 siswa dan rata-rata seluruh siswa yaitu 2,56. Rata-rata yang diperoleh masih rendah jika dibandingkan dengan KKM yang ditetapkan oleh sekolah yaitu 2,76. Tentu hal ini menjadi fokus permasalahan, apa yang menjadi penyebab sehingga hasil belajar matematika siswa masih rendah.

Selanjutnya berdasarkan hasil observasi yang dilakukan peneliti pada tanggal 17 November 2014 ketika proses pembelajaran berlangsung, ketika guru matematika menjelaskan materi baru, siswa secara umum terlihat memperhatikan dengan serius. Setelah selesai menjelaskan materi, guru memberikan latihan kepada siswa. Dengan pemberian latihan tersebut, masih ada siswa yang tidak mengerjakan, mereka menunggu hasil kerja teman sekelompoknya saja. Pada kegiatan mengkomunikasikan, guru memberikan kesempatan kepada siswa untuk mempresentasikan hasil diskusinya di papan tulis agar bisa dibahas bersama.

Berdasarkan hasil observasi di atas, terlihat bahwa walaupun guru sudah mencoba untuk menerapkan pembelajaran berkelompok, namun pada pelaksanaannya masih bersifat teacher center. Hal ini diindikasikan dengan guru masih menjelaskan materi, pembentukan kelompok tidak heterogen dan siswa kurang diarahkan rasa tanggung jawabnya terhadap tugas yang diberikan.

\footnotetext{
7 Nana Sudjana, Penilaian Hasil Proses Belajar Mengajar (Bandung: PT. Remaja Rosdakarya, 2008), 22.

${ }^{8}$ St Hasmiah Mustamin, "Meningkatkan Hasil Belajar Matematika Melalui Penerapan Asesmen Kinerja," Lentera Pendidikan 13, no. 1 (June 2010): 38.
}

Al-Khwarizmi - 33 
Berdasarkan permasalahan inilah maka perlu dilakukan perubahan cara pembelajaran yang bukan lagi terpusat kepada guru melainkan terpusat pada siswa dengan pembelajaran yang aktif, kreatif, efektif, dan menyenangkan. Untuk melakukan itu perlu disusun model pembelajaran dan dicarikan alternatif yang dapat mempengaruhi pembelajaran matematika tersebut. Salah satu alternatif yakni model pembelajaran penemuan terbimbing. Seperti halnya yang dikemukakan Markaban "model ini selain dapat mengembangkan kemampuan kognitif siswa, juga dapat meningkatkan kemampuan siswa dalam hal mengkomunikasikan matematika dan keterampilan sosial"9.

Salah satu model pembelajaran yang dapat diterapkan adalah model pembelajaran kooperatif tipe NHT. Hal ini dikarenakan kemampuan siswa dalam satu kelas beragam dan siswa yang berkemampuan tinggi lebih aktif dalam pembelajaran, sehingga diharapkan siswa yang berkemampuan tinggi dapat membantu siswa yang berkemampuan rendah dalam memahami materi pelajaran. Selain itu, tipe NHT dirancang untuk mempengaruhi pola interaksi siswa. Hal ini sejalan dengan Trianto yang menyatakan bahwa NHT atau penomoran berpikir bersama merupakan salah satu tipe pembelajaran kooperatif yang dirancang untuk mempengaruhi pola interaksi siswa dan sebagai alternatif terhadap struktur kelas tradisonal ${ }^{10}$.

Berdasarkan pendapat para ahli di atas, peneliti menduga bahwa model pembelajaran kooperatif tipe NHT berpengaruh terhadap aktivitas siswa dalam belajar matematika, yang pada akhirnya dapat mempengaruhi hasil belajar matematika siswa baik secara keseluruhan dan berdasarkan level kemampuan matematis (tinggi, sedang, atau rendah).

9 Markaban, Model Penemuan Terbimbing Pada Pembelajaran Matematika Smk (Yogyakarta: Pusat Pengembangan dan Pemberdayaan Pendidika dan Tenaga Kependidikan Matematika, 2008), 2.

10 Trianto, Mendesain Model Pembelajaran Inovatif-Progresif (Jakarta: Kencana Prenada Media Group, 2009), 82. 


\section{Metode Penelitian}

Penelitian ini merupakan penelitian eksperimen. Penelitian eksperimen yang dilakukan peneliti ialah quasi experiment atau eksperimen semu yang telah banyak dilakukan dalam dunia pendidikan. Sugiyono menyatakan bahwa bentuk penelitian eksperimen semu ini mempunyai kelompok kontrol, tetapi tidak dapat berfungsi sepenuhnya untuk mengontrol variabelvariabel luar yang mempengaruhi pelaksanaan eksperimen ${ }^{11}$.

Dalam quasi experimental design, peneliti memilih nonequivalent control group design. Desain ini menggunakan pretest yang berfungsi untuk mengetahui keadaan awal adakah perbedaan rata-rata hasil belajar matematika antara kelompok eksperimen dan kelompok kontrol. Sedangkan posttest digunakan untuk pengolahan data baik terhadap kelompok kontrol maupun kelompok eksperimen. Desain tersebut dapat dilihat pada tabel berikut:

Tabel 1. Desain Penelitian

\begin{tabular}{|c|c|c|c|}
\hline Kelas & Pengukuran (Pretest) & Perlakuan & Pengukuran (Posttest) \\
\hline Eksperimen & $\mathrm{O}_{1} \mathrm{E}$ & $\mathrm{X}$ & $\mathrm{O}_{2} \mathrm{E}$ \\
\hline Kontrol & $\mathrm{O}_{1} \mathrm{~K}$ & - & $\mathrm{O}_{2} \mathrm{~K}$ \\
\hline
\end{tabular}

Sumber: Modifikasi dari Sugiyono ${ }^{12}$

Keterangan:

$\mathrm{O}_{1} \mathrm{E} \quad$ : Hasil Pretest kelas eksperimen

$\mathrm{O}_{1} \mathrm{~K} \quad$ : Hasil Pretest kelas control

$\mathrm{X} \quad$ : Perlakuan yang diberikan, yaitu model pembelajaran penemuan terbimbing

- $\quad$ : Perlakuan yang diberikan, yaitu pembelajaran konvensional

$\mathrm{O}_{2} \mathrm{E} \quad$ : Hasil Posttest kelas eksperimen

$\mathrm{O}_{2} \mathrm{~K}$ : Hasil Posttest kelas kontrol

Sampel dalam penelitian ini diambil dengan teknik simple random sampling. Kelas VII terdiri dari $\mathrm{VII}_{1}$ dan $\mathrm{VII}_{2}$. Kemudian dari kedua kelas tersebut dilakukan undian untuk menentukan kelas eksperimen dan kelas kontrol. Dari hasil undian diperoleh kelas $\mathrm{VII}_{1}$ sebagai kelas eksperimen dan kelas $\mathrm{VII}_{2}$ sebagai kelas kontrol.

${ }^{11}$ Sugiyono, Metode Penelitian Pendidikan Pendekatan Kuantitatif, Kualitatif, Dan R \& $D$ (Bandung: Alfabeta, 2013), 114 .

12 Ibid., 116. 


\section{Model Pembelajaran Kooperatif Tipe Numbered Head Together (NHT) dan Hasil Belajar Matematika Ditinjau Secara Keseluruhan}

Berikut gambaran secara umum rerata hasil belajar matematika secara keseluruhan

Tabel 2. Statistik Deskriptif Postest Hasil Belajar Matematika Siswa

\begin{tabular}{|c|c|c|c|c|c|c|}
\hline \multicolumn{2}{|c|}{ Kelompok } & N & Xmaks & Xmin & $\bar{X}$ & Varians \\
\hline $\begin{array}{c}\text { Secara } \\
\text { Keseluruhan }\end{array}$ & Kontrol & 18 & 81 & 22 & 54 & 341,294 \\
\cline { 2 - 7 } & Eksperimen & 18 & 87 & 36 & 65,889 & 240,458 \\
\hline
\end{tabular}

Tabel 2 di atas memperlihatkan bahwa secara keseluruhan rerata hasil belajar matematika siswa kelas kontrol lebih kecil jika dibandingkan dengan rerata hasil belajar matematika siswa kelas eksperimen, dengan selisih rerata sebesar 11,889. Hal ini menunjukkan bahwa secara perhitungan rata-rata sudah terdapat perbedaan yang signifikan. Untuk menunjukkan bahwa apakah terdapat pengaruh penerapan model pembelajaran Kooperatif tipe NHT secara keseluruhan, maka dilakukan uji perbedaan rerata pada data postest dengan menggunakan uji Independent-Sample $T$ Test. Berikut rangkuman hasil uji perbedaan rerata pada data postest dengan taraf signifikan $\alpha=0,05$.

Tabel 3 : Uji Perbedaan Rerata Postest

\begin{tabular}{|c|c|c|c|}
\hline Kelompok & Pengujian & Signifikansi & Keterangan \\
\hline $\begin{array}{c}\text { Secara } \\
\text { Keseluruhan }\end{array}$ & $\begin{array}{c}\text { Uji Independent-Sample } T \\
\text { Test }\end{array}$ & 0,044 & Tolak $\mathrm{H}_{0}$ \\
\hline
\end{tabular}

$\mathrm{H}_{0}: \mu_{e} \leq \mu_{k}$ : Rata-rata hasil belajar matematika siswa kelas eksperimen sama atau lebih kecil dari rata-rata hasil belajar matematika siswa kelas kontrol, artinya tidak terdapat pengaruh penerapan model pembelajaran kooperatif tipe NHT terhadap peningkatan hasil belajar matematika siswa

$\mathrm{H}_{1}: \mu_{e}>\mu_{k}$ : Rata-rata hasil belajar matematika siswa kelas eksperimen lebih baik dari rata-rata hasil belajar siswa kelas kontrol, artinya terdapat pengaruh penerapan model pembelajaran kooperatif tipe NHT terhadap peningkatan hasil belajar matematika siswa 
Dari hasil uji perbedaan rerata postest di atas didapat nilai p-value atau Sig. (2-tailed) yaitu $0,044<\alpha=0,05$. Hal ini menunjukkan bahwa $\mathrm{H}_{\mathrm{o}}$ ditolak, artinya terdapat pengaruh penerapan model pembelajaran Kooperatif tipe NHT terhadap hasil belajar matematika siswa ditinjau secara keseluruhan. Secara keseluruhan terlihat bahwa model pembelajaran kooperatif tipe NHT dapat memberikan kontribusi yang positif bagi sebagian besar siswa dalam hal peningkatan hasil belajar matematika siswa.

\section{Model Pembelajaran Kooperatif Tipe Numbered Head Together (NHT) dan Hasil Belajar Matematika Ditinjau Dari Level Kemampuan Matematis Siswa (Tinggi, Sedang, Rendah)}

Berikut gambaran secara umum rerata hasil belajar matematika ditinjau dari level kemampuan matematis siswa (tinggi, sedang, rendah)

Tabel 4 : Statistik Deskriptif Postest Hasil Belajar Matematika Siswa

\begin{tabular}{|c|c|c|c|c|c|c|}
\hline \multicolumn{2}{|c|}{ Kelompok } & N & Xmaks & Xmin & $\bar{X}$ & Varians \\
\hline Kemampuan level & Kontrol & 4 & 81 & 49 & 68 & 236,67 \\
\cline { 2 - 7 } Tinggi & Eksperimen & 4 & 86 & 62 & 78 & 123,33 \\
\hline Kemampuan Level & Kontrol & 12 & 81 & 23 & 50,67 & 263,15 \\
\cline { 2 - 7 } Sedang & Eksperimen & 10 & 87 & 44 & 64,5 & 202,06 \\
\hline $\begin{array}{c}\text { Kemampuan Level } \\
\text { Rendah }\end{array}$ & Kontrol & 2 & 70 & 22 & 46 & 1,15 \\
\cline { 2 - 7 } & Eksperimen & 4 & 80 & 36 & 57,25 & 331,583 \\
\hline
\end{tabular}

Tabel 4 di atas memperlihatkan bahwa pada level kemampuan tinggi rerata hasil belajar matematika siswa kelas eksperimen lebih besar jika dibandingkan dengan rerata hasil belajar matematika siswa kelas kontrol, dengan selisih rerata sebesar 10 . Selanjutnya pada level kemampuan sedang rerata hasil belajar matematika siswa kelas eksperimen lebih besar jika dibandingkan dengan rerata hasil belajar matematika siswa kelas kontrol, dengan selisih rerata sebesar 13,833. Sedangkan pada level kemampuan rendah, rerata hasil belajar matematik siswa kelas eksperimen lebih besar jika dibandingkan rerata hasil belajar matematika siswa kelas kontrol dengan selisih rerata sebesar 11,25. 
Selisih rerata dari ketiga level kemampuan di atas, memperlihatkan bahwa selisih rerata yang paling besar adalah selisih rerata untuk hasil belajar matematika siswa pada level kemampuan sedang. Dengan itu peneliti menduga bahwa model pembelajaran kooperatif tipe NHT berkontribusi besar terhadap peningkatan hasil belajar matematika siswa pada level kemampuan sedang. Sedangkan untuk level kemampuan matematis siswa tinggi dan rendah, model pembelajaran kooperatif tipe NHT tidak memberikan kontibusi yang lebih besar jika dibandingkan dengan siswa pada level kemampuan sedang.

Untuk menunjukkan bahwa apakah terdapat pengaruh penerapan model pembelajaran penemuan terbimbing terhadap hasil belajar matematika siswa ditinjau berdasarkan level kemampuan matematis siswa (tinggi, sedang, rendah), maka dilakukan uji perbedaan rerata pada data postest dengan menggunakan uji Independent-Sample $T$ Test. Berikut rangkuman hasil uji perbedaan rerata pada data postest dengan taraf signifikan $\alpha=0,05$.

Tabel 5 : Uji Perbedaan Rerata Postest

Berdasarkan Level Kemampuan Matematis Siswa

\begin{tabular}{|c|c|c|c|}
\hline Kelompok & Pengujian & Signifikansi & Keterangan \\
\hline $\begin{array}{c}\text { Kemampuan } \\
\text { Level Tinggi }\end{array}$ & Mann-Withney & 0,309 & Terima $\mathrm{H}_{0}$ \\
\hline $\begin{array}{c}\text { Kemampuan } \\
\text { Level Sedang }\end{array}$ & $\begin{array}{c}\text { Uji Independent-Sample T } \\
\text { Test }\end{array}$ & 0,048 & Tolak $\mathrm{H}_{0}$ \\
\hline $\begin{array}{c}\text { Kemampuan } \\
\text { Level Rendah }\end{array}$ & $\begin{array}{c}\text { Uji Independent-Sample T } \\
\text { Test }\end{array}$ & 0,0643 & Terima $\mathrm{H}_{0}$ \\
\hline
\end{tabular}

$\mathrm{H}_{0}: \mu_{e} \leq \mu_{k}$ : Rata-rata hasil belajar matematika siswa kelas eksperimen sama atau lebih kecil dari rata-rata hasil belajar matematika siswa kelas kontrol, artinya tidak terdapat pengaruh penerapan model pembelajaran kooperatif tipe NHT terhadap peningkatan hasil belajar matematika siswa.

$\mathrm{H}_{1}: \mu_{e}>\mu_{k}$ : Rata-rata hasil belajar matematika siswa kelas eksperimen lebih baik dari rata-rata hasil belajar siswa kelas kontrol, artinya terdapat pengaruh penerapan model pembelajaran kooperatif tipe NHT terhadap peningkatan hasil belajar matematika siswa. 
Dari hasil uji perbedaan rerata postest untuk siswa pada level kemampuan tinggi di atas didapat nilai p-value atau Sig. (2-tailed) yaitu $0,309>\alpha=0,05$. Hal ini menunjukkan bahwa $\mathrm{H}_{\mathrm{o}}$ diterima, artinya tidak terdapat pengaruh penerapan model pembelajaran kooperatif tipe NHT terhadap hasil belajar matematika siswa pada level kemampuan matematis siswa tinggi.

Selanjutnya untuk siswa pada level kemampuan sedang, diperoleh nilai p-value atau Sig. (2-tailed) yaitu 0,048 $<\alpha=0,05$. Hal ini menunjukkan bahwa $\mathrm{H}_{\mathrm{o}}$ ditolak, artinya terdapat pengaruh penerapan model pembelajaran kooperatif tipe NHT terhadap hasil belajar matematika siswa pada level kemampuan matematis siswa sedang. Pada siswa dengan level kemampuan rendah, diperoleh nilai $p$-value atau Sig. (2-tailed) yaitu 0,0643 $>\alpha=0,05$. Hal ini menunjukkan bahwa $\mathrm{H}_{\mathrm{o}}$ diterima, artinya tidak terdapat pengaruh penerapan model pembelajaran kooperatif tipe NHT terhadap hasil belajar matematika siswa pada level kemampuan matematis siswa rendah.

\section{Penutup}

Berdasarkan penjabaran di atas dapat disimpulkan bahwa tidak terdapat pengaruh penerapan model pembelajaran kooperatif tipe NHT terhadap hasil belajar matematika siswa ditinjau dari level kemampuan matematis siswa (tinggi dan rendah). Sedangkan secara keseluruhan dan untuk level kemampuan matematis siswa edang, model pembelajaran kooperatif tipe NHT memberikan pengaruh. Setelah diperhatikan sesuai dengan pelaksaan penelitian, peneliti menduga hal ini terjadi karena:

1) Siswa pada level kemampuan tinggi menganggap pembelajaran yang dilakukan membosankan dan terlalu bertele-tele. Hal ini diindikasikan dengan siswa yang pada level kemampuan tinggi ingin segera melanjutkan kemateri berikutnya, tanpa memperhatikan temannya sudah paham atau belum. Sehingga siswa pada level kemampuan tinggi kurang menikmati dan memaknai proses penerapan pembelajaran.

2) Siswa pada level kemampuan rendah sebagian besar tidak siap dan takut dengan penerapan model pembelajaran kooperatif tipe NHT ini. Karena pada saat penerapan, ada penentuan nomor kepala yang akan dipanggil untuk memberikan jawaban. Kondisi inilah yang membuat siswa pada level kemampuan rendah merasa tidak nyaman dan takut. Tidak nyaman dan takut diakibatkan mereka tidak yakin dengan jawaban yang dibuatnya dan takut salah. 
3) Sedangkan siswa pada level kemampuan sedang, sebagian besar menikmati penerapan pembelajaran ini. Hal ini diindikasikan dengan sebagaian besar tidak merasa takut, tidak merasa terburu-buru untuk menyudahi pembelajaran dan yang paling terpenting mereka mau bekerjasama dan mempertanggung jawabkan apa yang sudah dikerjakan.

Dari penjabaran di atas, maka dapat disarankan bahwa dalam penerapan model pembelajaran kooperatif tipe NHT, peneliti selanjutnya harus dapat menyakinkan kepada semua siswa bahwa pembelajaran yang dilakukan tidak membuat siswa bosan, takut dan tidak percaya diri. Hal ini dapat dilakukan dengan cara memberikan motivasi-motivasi dan memperlihatkan kelebihan dari model pembelajaran yang diterapkan. Terutama pada saat fase pemanggilan kepala bernomor, guru harus bisa meyakinkan siswa bahwa dia mampu untuk tampil ke depan. Selain itu, untuk menarik perhatian siswa, perlu dipersiapkan untuk kepala bernomornya dengan yang lebih variasi, misal warnanya atau bentuk kepala bernomor yang dikenakan siswa.

\section{Daftar Pustaka}

Abdurrahman, Mulyono. Pendidikan Bagi Anak Berkesulitan Belajar. Jakarta: Rineka Cipta, 2003.

Markaban. Model Penemuan Terbimbing Pada Pembelajaran Matematika Smk. Yogyakarta: Pusat Pengembangan dan Pemberdayaan Pendidika dan Tenaga Kependidikan Matematika, 2008.

Mustamin, St Hasmiah. "Meningkatkan Hasil Belajar Matematika Melalui Penerapan Asesmen Kinerja." Lentera Pendidikan 13, no. 1 (June 2010): 33-43.

Purnomo, Yoppy Wahyu. "Efektivitas Model Penemuan Terbimbing Dan Cooperative Learning Ditinjau Dari Kreativitas Siswa Pada Pembelajaran Matematika," 2011. http://publikasiilmiah.ums.ac.id/bitstream/handle/123456789/609/ MAK-YOPPY-(145-154).pdf?sequence $=1$.

Reys, Robert E, Mary Lindquist, Diana V Lambdin, Marilyn Suydam, and Nancy L Smith. Helping Children Learn Mathematics. Boston: Allyn and Bacon, n.d.

S, Wardhani, and Rumiati. Instrumen Penilaian Hasil Belajar Matematika SMP: Belajar Dari PISA Dan TIMSS. Yogyakarta: Kementrian Pendidikan Nasional: Pusat Pengembangan dan Pemberdayaan Pendidik dan Tenaga Kependidikan Matematika, 2011.

Soedjadi. Kiat Pendidikan Matematika Di Indonesia. Jakarta: Direktorat Jenderal Pendidikan Tinggi Departemen Pendidikan Nasional, 2000.

Sudjana, Nana. Penilaian Hasil Proses Belajar Mengajar. Bandung: PT. Remaja Rosdakarya, 2008.

Sugiyono. Metode Penelitian Pendidikan Pendekatan Kuantitatif, Kualitatif, Dan $R \&$ D. Bandung: Alfabeta, 2013. 
Pengaruh Model Pembelajaran Kooperatif Tipe NHT ...

Suhermi, and Sehatta Saragih. Strategi Pembelajaran Matematika. Pekanbaru: Cendekia Insani, 2006.

Trianto. Mendesain Model Pembelajaran Inovatif-Progresif. Jakarta: Kencana Prenada Media Group, 2009. 
Hayatun, Rezi, Erdawati, \& Hasanuddin

Halaman ini sengaja dikosongkan

Al-Khwarizmi - 42 